\title{
Marriage in Islamic Interpretive Tradition: Revisiting the Legal and the Ethical
}

\author{
Mulki Al-Sharmani \\ Faculty of Theology, University of Helsinki, P.O. Box 59, 38 E Unioninkatu, \\ ooo14, Helsinki, Finland \\ mulki.al-sharmani@helsinki.fi
}

\begin{abstract}
This paper tackles the vexed relationship between the ethical and the legal in the patriarchal construction of marriage and spousal rights in Islamic interpretive tradition and its modern manifestations (i.e. contemporary Muslim family laws and conservative religious discourses). I approach the issue from two angles. First, I examine the work of selected Muslim women scholars from different countries, who since the late 1980 s and early 1990 s have been engaging critically with Islamic interpretive tradition, to unpack and critique patriarchal interpretations and rulings on marriage and divorce rights, and provide alternative egalitarian readings that are grounded in Quraanic ethics. Second, I shed light on how this patriarchal construction of marriage and gender rights impacts the lived realities of ordinary Muslim women and men. I focus on two national contexts: Egypt and Finland. I show-through analysis of courtroom practices in family disputes, marriage practices, and ordinary women's understandings of the sacred text-that the exegetical and juristic construction of spousal roles and rights is increasingly unsustainable in the lived realities of many Muslims as well as becoming a source of tension on an ethicoreligious level.
\end{abstract}

\section{Keywords}

Islamic interpretive tradition - gender - law - ethics 


\section{Introduction}

How are marriage and spousal rights constructed in Qu'rānic exegesis (tafsir $)$ and Islamic jurisprudence $(f i g h)$ ? How does this exegetical and juristic construction speak to the Qurānic ethos on marriage and gender relations? And how are present day Muslim women impacted by this hierarchical and gendered model of marriage which continues to be maintained (albeit in modified ways) in many contemporary figh-based Muslim family laws? This paper seeks to address these questions using a two-pronged approach.

First, I engage with the exegetical and juristic construction of marriage through a textual analysis of the relevant work of selected Muslim women scholars from Egypt, UK, USA, and South Africa. These scholars have been engaging critically with Islamic interpretive tradition, focusing on the question of gender and its relation to Qurannic ethics. Their starting point is a faithbased position: they believe in the normative role of their religious tradition; they have great deference for the interpretive tradition and do not seek to dismantle it or do away with it. Rather they are searching for answers to ethical and hermeneutical challenges from within. The work of these women scholars is situated in a larger scholarship which has been termed as Islamic feminism. ${ }^{1}$ And while the question of ethics and Islamic law in relation to gender has also been taken up by notable Muslim male scholars such as Khaled Abou El Fadl (Abou El Fadl 2014), what distinguishes these women scholars is their systematic engagement with this issue, as well as their collective efforts to link their intellectual work to building a global movement towards gender equality and justice in Muslim families. ${ }^{2}$

1 Elsewhere, I wrote about the contestations around the term Islamic feminism and the limitations of lumping together many divergent and un-connected projects underneath this label. I argue that there is, however, a conceptual, hermeneutical, and political framework that is shared by some of the projects and which I propose as the basis for studying them as part of a larger emerging body of knowledge building movement. See Al-Sharmani 2011, Al-Sharmani 2014c.

2 For example, in 2009, Ziba Mir-Hosseini and Amina Wadud, two of the scholars I discuss in this paper, co-founded with other Muslim women scholars and activists such as Zainah Anwar from Malaysia Musawah, a global knowledge building movement. Musawah links scholarship with activism, producing new collaborative religious feminist knowledge and undertaking advocacy efforts towards the goal of gender equality and justice in the Muslim families. See http://www.musawah.org/. As part of a multi-dimensional five year knowledgebuilding initiative on the concepts of qiwāmah and wiläah, Musawah brought together the studied scholars and others to conduct hermeneutical studies on these two concepts. See Mir-Hosseini el 2015. 
I focus, in this paper, on selected studies by Omaima Abou-Bakr, Ziba MirHosseini, Amina Wadud, and Sadiyya Shaikh. First, I show how the work of these scholars illuminates the processes through which patriarchal model of marriage and spousal rights was constructed in the tafsir literature, took legal shape in figh, and has been largely maintained in contemporary Muslim family laws and conservative religious discourses. Early exegetes and jurists based their understanding of marriage as a hierarchical relationship between men and women on their readings of relevant Qurānic verses on family relations-readings that were shaped by their socio-historical contexts. But their construction of marriage, according to the studied Islamic feminist scholars, undermines central Qurānic theological principles such as the equal worth and moral agency of all human beings, and the duty of every believer to live a life that truly reflects God's tawhìd by avoiding relationships of power, domination, and subordination.

Second, I look at how this exegetical/juristic construction of gender roles and rights in the family domain impacts the lived realities of marriage and divorce. I examine how ordinary Muslim women, in particular, wrestle with this legal/religious model in their daily lives. I focus on two contexts. One is Egypt: a Muslim majority context where the figh model of marriage is sustained in the country's codified family laws. The other context is Finland: a Western country where state family laws are secular; Muslims constitute a minority and draw on uncodified figh injunctions when contracting Islamic marriages. The goal is not to compare the two contexts. Rather I aim to show how the exegetical and juristic construction of marriage is at play in two very different contemporary settings; how the interlocutors in the respective contexts grapple with this legal/religious framework that shapes their marriages because of its increasing disconnect from their lived realities as well as the ethical dilemmas that it poses for them as they find it at odds with their understanding of the Qurānic vision on marriage and spousal relations.

\section{$2 \quad$ Research Data}

My analysis is primarily informed by the findings of three studies. I draw on a five year study (2013-2018) of selected interpretive knowledge projects, undertaken predominantly by Muslim women scholars, and which engage with Islamic religious sciences, driven by the question of gender justice. ${ }^{3}$ The

3 This Academy of Finland project (2013-2018) is titled 'Islamic Feminism: Tradition, Authority, and Hermeneutics' and is based at Faculty of Theology, Study of Religions Unit, University of Helsinki. 
focus of this research is twofold. The first is selected transnational knowledge projects $^{4}$ undertaken by a number of scholars who are working on the Qur'an and exegetical tradition; classical jurisprudence and its linkages to modern family laws; and Sufi thought. They are Amina Wadud; Asma Barlas, Omaima Abou Bakr, Ziba Mir-Hosseini, Kecia Ali, and Sa'diyya Shaikh. The second focus is a case study of Egyptian interpretive knowledge projects which have strong linkages and ties to the above-mentioned projects (but also these projects have their own context-specific particularities and divergences). In the case study, I have been focusing on the Arabic scholarship of Omaima Abou-Bakr and Hoda El Saadi at the research organization Women and Memory Forum. I have also been studying the collaborative Arabic scholarship that Abou-Bakr is producing with other Egyptian scholars who are conducting similar studies such as Amany Saleh and Hend Mostafa at the research organization Woman and Civilization. In addition, I have also been researching the advocacy work of a number of Egyptian non-governmental organizations which draw on this new scholarship in their efforts to promote gender equality. ${ }^{5}$ My research in this project involved close analysis of the works of the studied scholars, as well as interviews and participant observation.

My analysis is also based on the findings from a four year (2007-2010) qualitative study of Egyptian family laws and the reforms introduced since 2000. This study is based on a large body of data from interviews with different relevant actors, focus group discussions, court observation, and analysis of court records. ${ }^{6}$ (Al-Sharmani 2012, 2013a, 2013b, 2013c, 2014a, 2014b, 2017a).

In addition, this paper is informed by a four year ethnographic study (2013-2017) on Muslim marriage norms and practices in in Finland, focusing on migrants of Somali background as they comprise the largest Muslim community in the country. ${ }^{7}$ Research data was collected from individual women

4 I call the work of these scholars transnational for a number of reasons. These scholars are based in academic institutions in different countries in Africa, the Middle East, UK, USA, Canada. They produce scholarship in English and their published work is widely disseminated to both academic and non-academic readers.

5 One such organization is Mada Foundation, and its program Noon for gender and religious reform. The foundation, however, suspended its activities in October 2015. On the work of Islamic feminist scholars in Egypt and Mada Foundation, see Al-Sharmani 2016.

6 With the assistance of research assistants, Sawsan Sharif and Fayrouz Gamal at the Social Research Center, the American University in Cairo we conducted interviews with 194 male and female litigants about their disputes and court cases, and 100 men and women of different marital statuses about their marriage aspirations and practices; as well as interviews with 30 court personnel including judges and court-based mediators; 4 focus group discussions with lawyers, and interviews with legislators, religious scholars, and women's rights activists.

7 This research was one of three studies comprising a larger Academy of Finland project titled 'Transnational Muslim Marriages in Finland: Wellbeing, Law, and Gender.' 
and men as well as mosques working with Muslims families on marriage and divorce-related issues. ${ }^{8}$

\section{Revisiting the Ethical and Legal in the Interpretive Tradition: Islamic Feminist Scholars' Re-readings}

In a path-breaking study, the Egyptian scholar Omaima Abou-Bakr undertakes a genealogical critical reading of the exegesis of Qurānic verse 4:34 over the course of ten centuries (Abou-Bakr 2015). ${ }^{9}$ Abou-Bakr surveys the exegetical corpus starting with the 1oth century exegete Abū Ja 'far Muḥammad al-Ṭabārī (d.310/923) up till the 2oth century exegete Muhammad 'Abduh (d. 1905). She traces the development of qiwāma as a patriarchal construct that sanctions gender inequality and essentialist discourse on maleness and femininity. AbouBakr's analysis reveals the following exegetical trajectory of the development of qiwāma. First, exegetes turned 'qawwāmūn'10 in verse 4:34- from a description of a particular social organization of marital roles at the time of the revelation when men provided for women - to a prescriptive construct articulated through the use of the noun qiyām first and then later qiwāma to sanction male authority and superiority. Second, they came up with lists of qualities that they attributed arbitrarily to men and women to justify men's claim to authority and superiority on the basis of the constructed norm of qiwäma. For example, the exegete Abū al-Qāsim Mạ̣mūd ibn 'Umar al-Zamakhsharī (d. 538/1144) comprised a list of assumed male attributes which he claimed were the basis for men's right to divinely ordained preference (e.g. reason, resoluteness, determination, strength, writing, jihäd, etc.). Subsequent exegetes

8 I and post-doctoral researcher Abdirashid Ismail collected interview data from 37 women and men and 5 focus group discussions with a total 39 women and men. I also documented the life stories of 5 women. In addition, I collaborated with post-doctoral researchers Sanna Mustasaari and Abdirashid Ismail in researching 8 mosques in Helsinki that conclude Islamic marriages and undertake mediation and arbitration in family disputes. In particular, I conducted an in-depth four year ethnographic study of one Helsinki mosque, taking part in and observing its various activities for families. See Al-Sharmani et al 2017; Mustasaari and Al-Sharmani 2018, Al-Sharmani forthcoming.

9 A translation of verse 4: 34 reads, 'Men are the protectors and maintainers of women, because Allah has given the one more (strength) than the other, and because they support them from their means. Therefore the righteous women are devoutly obedient, and guard in (the husband's) absence what Allah would have them guard. As to those women on whose part ye fear disloyalty and ill-conduct, admonish them (first), (Next), refuse to share their beds, (And last) beat them (lightly); but if they return to obedience, seek not against them Means (of annoyance): For Allah is Most High, great (above you all)' See Abdullahi Yusuf Ali translation, 1989.

10 Qawwām, an adjective, is derived from the Arabic verb yaqūm 'alā, which means to take care of, to manage. 
such as Muḥammad ibn 'Umar Fakhr al-Dīn Al-Rāzī (d 6o6/1209); 'Abd Allāh ibn 'Umar al-Baiḍāwī (d. 685/1286), Abū 'Abd Allāh al-Qurțubī (d. 671/1273), and 'Imād al-Din Ismā'il ibn 'Umar Ibn Kathīr (d. 701/1301), further developed listing binaries of male and female attributes to justify their constructions of qiwāma-based male superiority and privileges. Third, the concept of qiwāma was linked to verse 2:228 and the notion of men having 'degree' over women that is expressed in this latter verse in order to re-enforce the hierarchal meaning of qiwāma although verse 2: 228 is located in a unit of verses that tackles the theme of divorce and its central message is to urge both parties not to do injustice to one another. ${ }^{11}$ Fourth, exegetes of modern times further cemented the meaning of qiwāmah by ascribing inherent domesticity to women versus inherent intellectual superiority and leadership in men.

Abou-Bakr examines Muhammad 'Abduh's exegesis of qiwāma as an example of this kind of modern religious discourse, shedding light on his concept of men's riyāsa (rule) over women, and his argument for leadership and intellectual superiority as innate male attributes on the grounds of a notion of biological determinism that is extended to all male versus all female species (human and non-human). Abou-Bakr, in particular, highlights how 'Abduh's modernist exegesis, unlike that of the pre-modern, constructs and reinforces a domestic role for women that included not only child care but also the housework (Abou-Bakr 2014). She notes the importance of recognizing the significant distinction between pre-modern and modern patriarchy as illustrated in the exegetical corpus. Pre-modern exegetical discourse certainly privileged men and subordinated women, but it also stressed men's duty to protect women, to be good husbands and fathers, not to do zulm (injustice) to their wives and made their privileges linked to men's fulfillment of these duties as part of their religious duty to actualize taqwā (God consciousness). Modern exegetical discourse, however, is centered around modernist understandings of innate female domesticity and male rationality and leadership, resulting in clear-cut divisions between private female-centered domain and public male-centered domain. Abou Bakr points out that the patriarchy of this modernist exegetical discourse is more detrimental to women because it shifted attention away

11 A translation of verse 2:228 reads, 'Divorced women shall wait concerning themselves for three monthly periods. Nor is it lawful for them to hide what Allah Hath created in their wombs, if they have faith in Allah and the Last Day. And their husbands have the better right to take them back in that period, if they wish for reconciliation. And women shall have rights similar to the rights against them, according to what is equitable; but men have a degree (of advantage) over them. And Allah is Exalted in Power, Wise.' See Abdullahi Yusuf Ali translation, 1989 . 
from men's duties and obligations and focuses entirely on women and their essentialized nature and roles (Abou-Bakr 2014).

Abou-Bakr's genealogical reading of constructs such as qiwāma demystifies the exegetical tradition. It is no longer seamless, unchangeable, and sacred but rather historically-based religious knowledge that can be revisited. In another relevant work, Abou-Bakr uses what she called 'Islamic cultural analysis' or intertextuality, to examine how different texts in the tradition speak to one another, revealing tensions between their patriarchal and egalitarian iterations (Abou-Bakr 2012). She juxtaposes, for example, the exegetical work of Ibn Kathīr and al-Suyūti who lived in the 15th century to the biographical dictionary of their contemporary, the historian and hadìth scholar al-Sakhāwī. Abou-Bakr's goal is to shed light on how meanings and concepts traveled in the textual tradition; how they were reinforced and built on, or refuted and displaced; where hidden and alternative meanings and discourses can be found and unearthed. (Abou-Bakr 2012, 7) She notes, for example, that while al-Sakhāwì was describing hadīth women scholars using terms such as "rational, judicious, and of intelligent mind, and leading in mind and in religion," Ibn Kathīr and al-Suyūți were writing about wifely obedience and ascribing subordination and inferiority to women, drawing on prophetic hadith that claims women are deficient in intellect and religion. In other words, Abou-Bakr shows that Islamic interpretive tradition is not "monolith but contains within it signs of counter-discourse as well." (Abou-Bakr 2012, 7).

The hierarchical model of marriage found in the exegetical corpus is also mirrored in Islamic jurisprudence ( $f$ igh), which is concerned with deducing rulings from the textual sources to regulate social relations. Figh constructs spousal duties and rights as interdependent, gendered, and unequal. A husband is obligated to give his wife dower and provide for her in exchange for her obedience $\left(t \bar{a}^{\prime} a\right)$ (Mir-Hosseini 2003, Ali 2003, Abu Odeh 2004, Tucker 2008). Wife's obedience in legal terms means her obligation to reside in the marital home and to avail herself sexually to her husband. These rulings were based on jurists' interpretations of Qur'ānic verse 4:34. In this juristic model of marriage, there are no shared matrimonial resources. Whatever possessions and assets the wife brings to the marriage remain hers. Likewise, apart from maintenance for herself and her children, the wife cannot make claims to resources acquired by the husband during marriage. In addition, the husband has unilateral right to repudiation and polygamy, while the wife's access to divorce is restricted; and is secured either judicially on the grounds of specific fault-based reasons, which differ from one school to the other, or through negotiation with the husband, often involving her forfeiting her financial rights. 
Unpacking the juristic construction of marriage, the Iranian UK-based Ziba Mir-Hosseini notes how jurists defined the marriage contract as a "contract of exchange and patterned on the contract of sale," whose objective was to make sexual relations between the two contracting parties licit (Mir-Hosseini 2013, 10). This marriage contract stipulates a set of rights for both spouses, some legally enforceable, and others subject only to moral sanctions. The rights and duties that carried legal weight focused on a husband's duty to provide versus wife's duty to be obedient; and husband's right to repudiate or take multiple wives. But the abuse of the right to unilateral repudiation or polygamy, for instance, was merely subject to moral sanction. Still pre-modern jurists, MirHosseini adds, were concerned about the welfare of women: they warned husbands against doing injustice to women and put in some checks on husbands' authority and privileges (e.g. they linked men's right to unilateral repudiation with payment of financial rights that were due to the wife; they restricted a husband's authority over his wife to sexual access; and they regulated the ways in which a husband could discipline his wife). But their very construction of the marriage contract, its goal, and the particular rights and duties that were privileged overshadowed the ethical essence and purpose of Islamic marriage as defined in the Qur'an. Furthermore, this juristic construction of the marriage contract and its underlying concept of men's qiwāmah over women, shared by all schools notwithstanding differences among them, became the foundation or the "DNA of patriarchy in modern Muslim family laws." (Mir-Hosseini and Anwar 2012)

The insights from Abou-Bakr and Mir-Hosseini's hermeneutical engagements with tafsir and figh respectively are particularly relevant for contemporary Muslim contexts where dominant religious discourses often sanctify and essentialize Islamic textual tradition, depicting it as monolithic, fixed, and sacred. Such discourses and its challenges are illustrated, for example, through the argument put forward by the Egyptian Azhar scholar of Islamic Jurisprudence, Soad Saleh. In a religious talk show entitled Ammā Yatasäalün (What are they Asking About) aired on the Egyptian satellite channel Dream 2, on June 20, 2009, Saleh was asked whether there was a need for an interpretation that restricts or even bans men's right to polygamy, given the problems that had been found to arise from polygamous marriages, and which impact co-wives and children (e.g. men leaving their multiple wives without support, failing to provide adequate care and education for their children, etc.). Saleh's answer was if polygamous men were failing to be good Muslims who treat their co-wives equally and take care of their children, then this was a problem with the men and not a reason to go against God's sacred text, which according to 
Saleh, sanctions polygamy. ${ }^{12}$ In other words, Saleh's argument assumes there is a perfect text-based religious doctrine which is applicable to Muslims at all times and in all places. And if the doctrine does not serve justice or creates injustice, it is because either Muslims are applying it erroneously or are failing in piety. Her interpretation not only fails to link context and text in a nuanced and dynamic fashion but also takes dominant exegetical interpretations sanctioning polygamy as an immutable given. In other words, these interpretations become conflated with the Qur'ānic text itself.

Egyptian religious scholars' opposition to the new khul' divorce-when it was first passed in 2000-was also based on a similar logic that sanctified Islamic jurisprudence. The new law grants Egyptian women to petition for judicial khul' divorce, irrespective of a husband's consent. Female petitioners in such cases are guaranteed court issued divorce without having to prove any fault-based grounds for their petition provided that they relinquish their right to the dower and other post-divorce financial dues (Al-Sharmani 2012). The opponents of the new law argued that the Egyptian legislator departed from the Islamic Sharĩah. since the majority opinions in most juristic schools assume that a wife seeking khul' divorce has to negotiate with her husband and secure his consent. ${ }^{13}$

While the works of Mir-Hosseini and Abou-Bakr and others focus primarily on identifying the epistemological and ethical gaps in Islamic interpretive tradition (i.e. diagnosing the problem), perhaps the African American scholar Amina Wadud takes a step further by providing an alternative framework for reform from within the sacred text. Wadud calls for Qur'ānic hermeneutics that undertakes "analyses of the ethical moral intent" of the sacred text. (Wadud 2004, 330). Wadud points out that at the core of the Qur'an's worldview is the 'ethics of tawhid' (Wadud 2015). She argues that tawhid is the essence of the Qur'annic message to human beings and is the guiding framework for human-God relation and human-human relations. Thus, all social relations

12 Exegetical interpretations which sanction polygamy are based on Quranic verse 4:3 which reads,' If ye fear that ye shall not be able to deal justly with the orphans, marry women of your choice, two or three or four; but if ye fear that ye shall not be able to deal justly (with them), then only one, or (a captive) that your right hands possess, that will be more suitable, to prevent you from doing injustice.'(Youssef Ali Translation).

13 Juristic rulings on khul' are based on Quranic verse 2:229 and the Prophetic hadith that narrates: Jamila the wife of Thabit ibn Qays went to Prophet Muhammad seeking divorce from her husband. She said he had not wronged her in any way but she did not wish to stay in the marriage and feared she might transgress against God's limits if she continued with the marital union. The Prophet granted her the divorce after he had her return to the husband the garden which he gave her as a dower. See al-Bukhārī, 1974, 7:150-51. 
(including gender) and practices need to reflect the actualization of tawhid. (Wadud 2015, 258).

Tawhì, Wadud explains, has three important dimensions. First, it is premised on the central truth that God is one. Second, all attributes of God and their essences are in harmony and unity. Thus, attributes of God that may seem to be contradictory (e.g. wrath, mercy, being the first and last, the apparent and the hidden, etc.) are in fact in absolute harmony. And God created the world, including the human female and male, in dual forms, and each in their own inner reality as well as together reflect the Divine reality of oneness and harmony. Third, an important dimension of tawhìd is that 'God unites' and brings together differences. This has important implications for social relations (and in turn for gender relations). It means that perceived differences between people should be guided by the principle of tawhìd, which is grounded in the principle "of unity above hegemony," and requires "reciprocity, equality and harmony in all human relationships." (Wadud 2015, 267) And so if tawhìd as a central theological principle of Islam is to be implemented on both the individual and collective levels, it would be a counter construct for qiwäma, since the latter sanctions unequal gender relations and male superiority and thus contravenes with the essence of tawhid.

The South African scholar, Sadiyya Shaikh, also puts forward a corrective to the construction of gender in Islamic law, through a Sufi-oriented engagement (Shaikh 2015). Sufism, Shaikh points out, reminds us of the essence of human existence and the core theological principle that underlies Islam, which is submission to the Divine. The actualization of this goal entails the pursuit of the spiritual and ethical path towards the knowledge, love, and worship of God. Drawing on the work of the 13 century Sufi scholar Ibn 'Arabi, Shaikh notes that all human beings, whether men or women, are ontologically and spiritually equal and have equal potentiality for moral agency to seek the path. In other words, women and men-carrying the divine spark within - have the potentiality to realize the ethical ideal within them, and thus are able to manifest and unite God's attributes (i.e. balance jalälì attributes such as power and wrath and jamāli attributes such as mercy and gentleness). And since spiritual and social life are expected to be interconnected, an ethical way of being and living needs to be also reflected in the laws governing social (and thus gender) relations. This inherently necessitates striving against the desire for control, domination, and hierarchy, attributes that lie at the core of patriarchy. Therefore, figh being part of this religious tradition needs to be reformed in a way that reflects the theological and ethical essence of the faith.

To conclude, for the above-mentioned Islamic feminist scholars, the question of gender in the Islamic interpretive tradition is not confined to the issue 
of inequality and injustice that women suffer because of a hierarchal model of marriage and spousal rights. It is first and foremost a problem that arises from the disconnect between the exegetical and juristic construction of marriage and divorce on the one hand, and the core theological and ethical principles that underlie the Qur'an on the other hand.

\subsection{Revisiting the Ethical and Legal in Lived Realities of Muslim Marriages and Gender Relations \\ 2.2.1 Egypt}

How is the patriarchal model of marriage in the interpretive tradition relevant to contemporary Muslim family laws, both in a Muslim-majority context and in a diaspora context where the Muslim population are a minority and predominantly of migrant background? First, let us take Egypt as an example of the former. The construction of spousal roles and rights in Egyptian family laws draws on the figh model of marriage. Article 1 in Egypt's Personal Status Law No. 25 of 1920 (amended by PSL No. 25 of 1929 and PSL No. 100 of 1985) stipulates that 'maintenance shall be the wife's right and due on her husband from the authentic date of the contract if she shall have given herself to him in marriage even if virtually and despite her being wealthy or different from him in religion.' Thus, marital roles are defined, like in the figh corpus, as the husband being a provider for his wife, while the role of the latter is to be sexually available to the husband. To fulfill this role, the wife is expected to be 'obedient' to her husband. The code defines wifely obedience indirectly by defining its opposite, namely disobedience or nushüz. Article 11 defines nushüz as a wife's illegitimate refusal to reside in the matrimonial house, and stipulates that a wife who is found to be disobedient by the court loses her right to spousal maintenance (Al-Sharmani 2013b, 39).

But how does this legal script of spousal duties and rights play out in the lived realities of marriage and marital disputes? In my research on Egyptian family law reforms, the majority of the female respondents reported that they contributed significantly to the financial costs of their weddings and the furnishing of the conjugal home. In fact, this was a prevalent practice, particularly among the lower middle class. In addition, many of the married respondents also contributed substantively to the maintenance of the conjugal family and in some cases they were the sole providers due to their husbands' absence; on or off-abandonment; or underemployment/unemployment.

Also, my analysis of obedience ordinance court cases showed that husbands and wives were involved in such lawsuits for a variety of reasons that were related to the incongruence between their lived realities and the legal script of spousal roles (Al-Sharmani, 2013b, 41). Family law does not grant women 
any rights in return for their financial roles. This contributes to marital conflicts. Some female respondents wanted to work. Others needed to work even though they made little income and lacked the work benefits that would facilitate their juggling work, child care, husband care, and housework. These women felt ambivalent about work because they were caught in a situation in which their husbands failed to provide for them and their children adequately and thus could not relieve them (the wives) from being trapped in difficult and poorly paid work. Husbands were often reluctant for their wives to work but felt frustrated that they could not provide for them. Yet, these men still wanted to claim the power and authority over their wives which they obtained from their roles as providers/guardian. And in cases of marital conflicts, they used this power arbitrarily and excessively, resulting in physical abuse to their wives. Consequently, wives left the matrimonial house because they could not sustain a situation in which they were not provided for, were subjected to abuse, and were not allowed to earn their own income. Husbands responded by invoking the authority of their qiwāma, and filing an obedience ordinance against their wives. Husbands also filed for an obedience ordinance to offset a wife's efforts to seek judicial divorce; to negotiate for more advantageous financial settlement as part of the divorce process; or to use the claim to obedience as leverage to renegotiate with the wife the nature of their financial obligations as the legal providers.

Women's motivations to contest obedience ordinance were multiple and were often not about seeking maintenance. Some of these reasons included: claiming a matrimonial house that was separate from the dwelling of the inlaws, negotiating their right to work, and facilitating their pursuit of divorce. The connection between divorce and obedience cases suggests that the hierarchical marital relations created by the concept of qiwāma are not confined to the idea of maintenance versus obedience but also include the right to divorce. Men have unfettered right to it, whereas women's right to divorce is restricted because it is granted and managed through the court. And obedience ordinances are one of the mechanisms through which women's right to divorce is restricted. By filing for obedience, men forced their wives to undertake the task of contesting the husband's right to obedience.

Litigants' strategies in khul' divorce cases were also telling of the problems that women confronted as a result of unequal divorce rights. First of all, women's motivations for petitioning for khul'showed that many made use of this new legal reform not as a way to exercise the option of ending an unwanted marriage to a blameless partner in exchange for relinquishing their financial rights as this divorce was intended to be according to the textual sources in the Qur'an and Sunnah. Rather female litigants often used this legal option 
to avoid the insurmountable problems with the legal process and evidentiary requirements in fault-based divorce. That is, such women were often in marriages where they were being harmed by their spouses for a variety of reasons, but they opted not to petition for fault-based divorce because of its legal challenges. For example, in sixty nine of the hundred khul' cases that I researched, the female litigants petitioned for this divorce because of reasons such as: husbands' failure to support; spousal abuse (physical and sexual); husband's infidelity; husband's polygamy, husband's abandonment, etc.

Khul' cases not only illuminated the challenge of women's access to divorce in fault-based divorce, they also shed light on how entrenched is the patriarchal gender discourse that underlies the figh-based model of spousal rights and which continues to exist in Egyptian family laws. For instance, respondents from diverse groups (e.g. judges, court mediators, lawyers, male litigants) expressed to me their opposition or reservation to khul', making arguments that were premised on male intellectual and moral superiority versus female irrationality and fickleness. These arguments, moreover, were frequently grounded in the concept of men's claim to qiwamah. One husband put it as follows: "The man no longer has qiwämah over his wife, especially after khul'. If he says anything to her that she does not like, she tells him I will divorce you." Interestingly, some husbands filed obedience ordinance against their wives in khul' even though it was a given that the women would win these cases since they were forfeiting their right to spousal maintenance (and dower) by petitioning for khul' and thus owed no obedience to their husbands. But this tactic on the part of husbands was meant not only to prolong the legal process but also to re-affirm men's claim to authority and privilege by invoking the spousal maintenance-obedience claim, despite its being legally toothless in the cases of khul' divorce.

But it was not only the multidimensional problems encountered by women both inside and outside the courtroom that made this hierarchical figh-based model of spousal roles and rights a source of tension for women. Women also wrestled with the current family laws on an ethical level because they believed these laws departed from the ethical values of Islamic Sharitah, which they believed to be found in the Qur'ānic text (Al-Sharmani 2017a). They questioned, for example, marital sex as being conceived both in legal and religious discourse as the wife's obligation upon which her right to spousal maintenance is dependent. Many female interlocutors in the study believed that the Qurān advocates marriage relationships that are based on care and reciprocity, which they did not see reflected in the country's family laws or social norms. They often quoted Qurānic verse 30:21which defines marriage as sakan (tranquility), mawadda (affection) and rahma (compassion). They also believed that 
men's right to unilateral divorce and women's restricted access to divorce were at odds with how they understood the text's view on gender relations, invoking Qurānic terms such as ma'rüf (that which is commonly known to be good), ihsān (doing the good and beautiful), and 'adl (justice). It is noteworthy that female respondents who voiced these opinions did not study the Qur'an or the religious tradition closely. Still they were quite familiar with Qur'anic language and ethical terms, which were particularly relevant to verses on marriage, divorce, and polygamy. ${ }^{14}$ Moreover, for some of these respondents their own personal experiences with marital disputes and litigation enabled them to reflect on the relationship between the Qur'anic text and the family laws that were regulating their rights in marriage.

In short, the patriarchal model of marriage found in Egyptian family laws is increasingly becoming a source of tension to women and men because of its disconnect from their lived realities as well as its ethical shortcomings.

\subsubsection{Finland}

But what about Muslim women in a Western context where they are part of a religious minority? How is the figh-based model of marriage relevant in such a context? I examine the Finnish context as an example. Finland is a Nordic country with a population of 5,5 million and has been for most of its history a country of emigration (Statistics Finland 2018). Since the late 1980s, however, Finland has become increasingly a country of immigration. Muslims in the country are estimated to be round 60,00-65,000 (Pauha and Martikainen 2014). Tatars who moved from Russia in the 19th century are the oldest Muslim community, currently comprising about 600 people. Other Muslim communities are more recent arrivals to the country, immigrating from the Middle East, North and East Africa as well as South Asia. Most of the Muslim immigration to the country is refugee-based. Somalis, who first arrived in the country in the late 1980 s and early 1990 after the advent of the civil war in their home country, constitute the largest Muslim community with a total number of 19,059 (Statistics Finland 2016). The Somali community confront high unemployment rate, low socioeconomic level, low enrolment in higher education, and high instances of racism (OSF 2013). Among the younger generation, women are doing better than boys in school education. Furthermore, the gender-sensitive welfare policies of the country enable immigrant women to be more likely to

$14 \quad M a^{\prime} r u \bar{f} f$ is used repeatedly in verses on marriage and divorce, for example in 2:228, 2:229, 231, 232, 233, 234, 235, 236. Ihsān is also used in verse 2:229 as the basis for the Quranic framework for divorce. 
be economically autonomous from their spouses and contribute to the marginalization and stigmatization of immigrant men (Peltola 2015).

According to the Finnish 2008 Act of Performing Marriage Ceremonies, marriages have to be registered at the state notary office in order to be recognized as legally valid. Mosques which are registered as religious community are licensed to conduct religious marriages and are obligated to coordinate the task of registering these marriages with the state notary. ${ }^{15}$ Hence when marrying, many Somalis usually follow two-tier process. They conduct a religious marriage, and have it registered either by concluding the marriage at one of the licensed mosques, or having a religious scholar conclude the marriage in their homes and registering their marriages themselves. When conducting an Islamic marriage, Somali immigrants follow the main juristic doctrines shared by most schools. The bride's guardian (usually her father) acts on her behalf in concluding the marriage. The bride's guardian makes the offer (ijäb), and the groom accepts $(q u b \bar{u} l)$. A dower is agreed upon and entered in the marriage contract and two witnesses attest to the contract. Interestingly, more young women have been making use of the Hanbali doctrine of negotiating for stipulations to be entered into their marriage contracts. Women have been mainly inserting stipulations to negotiate to safeguard themselves from polygamy. This recent practice among young Somali women was not previously known among Somalis in diaspora or in the home country where the population predominantly adhere to the Shäfii school (Al-Sharmani 2015, 2017b). This new practice and others (e.g. claiming all of the dower either at the time of officiating the contract or sometime during the marriage) are related to increasing number of Somali women actively seeking religious education from diverse sources such as mosque classes, online lectures, published books, and educational visits to the Middle East. The pursuit of a reflective religious understanding has been part of these women's goal of leading an ethical and meaningful life as they confront on the one hand racism and marginalization in the larger society and on other hand gender-based challenges within the community.

And so as young women, in particular, have been increasingly acquiring more religious knowledge, they have been grappling with the uncodified religious (and cultural) laws regulating their intimate relationships. For example,

15 Religious groups can register as a religious community either under the Freedom of Religion Act of 2003 (with a minimum of 20 members) or under the Association Act of 1989. Communities registered under the former have to meet more rigid criteria than those registered under the latter law, but they enjoy more rights such as the legal authority to conclude marriages and the right to religious education. Registered religious communities are entitled to receive annual financial assistance from the state if they have at least 200 registered members. See Kääriäinen, 2011. 
twenty-five year old Nefisa argued that Muslim spousal roles should not be fixed but to be renegotiated as part of a larger religious process of cultivating a spiritually refined Muslim self and to lead a life of taqwā:

Islamically also for me, as a woman, it is extra ajir (reward from God) if I share with him the responsibility..... for me, it obviously made sense. It was no way his pay alone would cover everything. So Islamically I would get ajir and it was in my best interest, so why not.... We used to have this conversation with other Somali girls about the finances and whether you should contribute or not in the household. I know a couple of girls who would say 'No, No, why would I share the money with him (their husbands)? Let him provide for me.' And it never made sense to me, it did not feel right. I thought that is not very clever. At the end of the day he is not some random guy, it is your husband, you should act as a family, you should be concerned about him. Otherwise, it is just some business arrangement in the house. So, this idea that this is mine felt absurd to me.

AL-SHARMANI 2015, 111

Samira, a twenty year old university student critiqued Somali diasporic marriage norms, which while they discursively upheld juristic constructions of spousal roles (i.e. provision versus obedience) marginalized, in her view, an ethically-grounded Islamic model of marriage, based on the Prophet's role model as a husband and on key Qur'ānic values that foreground love, compassion, and reciprocity in a Muslim marriage:

I read a lot about the Prophet and about Islamic marriage. There is no love in Somali marriage. I wanted to understand the difference between our culture and what religion actually teaches us. I found there is a big difference: for Somalis, love is 'eeb' (shameful, taboo); they do not say I love you to one another, they do not send text messages to each other; they do not show affection to one another. But in our religion marriage is 'mawwadah wa rahmah' (affection and mercy). The Prophet was our role model, was gentle, playful, affectionate with his wives. He would drink milk from the same place as Aisha drank, he would race her, he would be patient when she got jealous and got mad at him. Couples, as it says in the Qurān are libās (garments) to one another.

AL-SHARMANI 2015, 114

Again adopting an ethically-guided framework that is grounded in the Qur'ān, interlocutors such as Nefisa and others also rejected polygamy because they 
saw it as contravening with the higher goal of cultivating an ethical Muslim self that is in harmonious relations with others. Nefisa, who inserted a stipulation against polygamy in her marriage contract, argued that polygamy would inevitably result in marital conflicts between her and her husband and thus would get in the way of a harmonious marital relationship that would enable her to cultivate an ethically responsible Muslim self, in preparation for the afterworld and accountability to God. Another interlocutor who got divorced from her husband when he remarried used similar argument: she was opposed to polygamy because she believed it resulted in spouses' failure to provide mawwadah (affection) and rahmah (compassion) to one another, and which she saw as integral to Islamic marriage and the goal of raising a good Muslim family together.

It is important to note that these women are not part of a feminist movement seeking gender equality. Their questioning of prevalent religious and cultural norms on marriage has been taking place in the context of their search for an ethical and empowering life in a migratory context where they face different challenges but where they are also being presented with new opportunities, including access to diverse forms of religious knowledge.

It is also noteworthy that the revisiting of patriarchal construction of fixed and hierarchical spousal roles and rights among Somalis in Finland has not been confined to this group of women. It is also being done (albeit in complex and mixed ways) by one of the main Somali-led mosques in Helsinki, in the course of its program activities for Muslim families. This mosque program has been educating men and women about Islam, family relations, and living in diaspora. ${ }^{16}$ It advocates, for instance, the need to rethink husbands' assumed religion-based authority over their wives or fixed marital roles whereby men's role as a provider is privileged, for instance, to his role as a care providing parent for his children-particularly that the latter role is what is more needed and beneficial to families. The mosque has been promoting this new religious understanding of spousal roles, using arguments that emphasize the importance of grounding religious laws and norms in clear ethical purposes. For example, the mosque imams question how men use (and abuse) their privileged divorce rights when they refuse to divorce their wives in mosque-mediated divorce disputes. The imams frame such acts as an ethical failure on the part of these men which makes their claim to Muslim piety diminished.

16 I have been conducting a four-year ethnographic study of this mosque program, and how the Finnish state governance of religious minorities enables and limits these kinds of initiatives. See Al-Sharmani, forthcoming. 
Again these mosque actors, like the women, are not seeking gender equality. Nonetheless, they are engaged in processes of reeducating Somali Muslim families about Islamic law and how it should govern their intimate relationships in ways that highlight the importance of linking the ethical and legal and taking into account the lived realities of the parties concerned.

\section{Conclusion}

In this paper, I reflected on the normative and ethical challenges of Islamic textual tradition in relation to the question of gender. This tradition, in many present day Muslim contexts, has multiple layers: it consists of classical tafsir and $f i g h$; it is linked to modern exegesis; it also has a foundation in modern family laws and dominant religious discourses. These individual layers of the tradition are not one and the same and hence collapsible to a singular entity. Notwithstanding the significant differences among these layers, I have argued that there is a particular construction of marriage and spousal duties and rights that is recognizable in all of them and is partly what links them together in one tradition.

This model of marriage creates challenges on multiple levels. I have examined, one level, its theological, ethical, and hermeneutical challenges through the epistemological engagements of selected Islamic feminist scholars from the Middle East, Africa, Europe, and North America. These scholars problematize the construction of gender in Islamic interpretive tradition through their critical rereading of tafsir and figh literature and provide alternative readings based on their interpretive insights from the sacred text and its theological principles. The goal of this Islamic feminist scholarship is twofold: to partake in an epistemological critique that situates itself within the tradition and to produce Islamically-grounded feminist knowledge that facilitates reaching the goal of gender equality and justice through multidimensional reform (legal, religious, social).

I have also traced how this model of marriage and gender rights is visible and at work in two very different Muslim contexts, and how women, in particular (but also religious institutions in a diasporic context) grapple with the legal, social, and ethical challenges arising from this model, particularly as the lived realities of marriage and gender roles are changing and women are becoming more versed in their sacred text and religious tradition.

The actors I discussed in this paper are diverse with different contexts and goals. However, it is precisely because of their diversity that what unites them is significant. They all embrace Islam as a faith and divinely-inspired normative 
framework for their lives, and they are all in search of the ethical in this framework, in order to foreground it and link it meaningfully to the legal.

\section{Bibliography}

Abou-Bakr, Omaima. "Islamic Feminism and the Production of Knowledge: Perspectives from Post-revolutionary Egypt." In Feminismes Islamiques (Islamic Feminisms), edited by Zahra Ali, 165-84. Paris: Le Fabrique Editions. (English version of the French article, written by the author).

Abou-Bakr, Omaima. 2014. "Turning the Tables: Perspectives on the Construction of Muslim Manhood." Journal of Women of the Middle East and the Islamic World, 11: 89-107.

Abou-Bakr, Omaima. 2015. "The Interpretive Legacy of Qiwamah as an Exegetical Construct." In Men in Charge? Rethinking Authority in Muslim Legal Tradition, edited by Ziba Mir-Hosseini, Mulki Al-Sharmani, and Jana Rumminger, 44-64. Oxford: OneWorld.

Abou El Fadl, Khaled. 2014. Reasoning with God: Reclaiming Shariah in the Modern Age. Lanham, Maryland: Rowman and Littlefield.

Abu Odeh, Lama. 2004. "Modernizing Muslim family law: The case of Egypt', Oxford University Comparative Law Forum 3. Accessed 10 April 2018. http://ouclf.iuscomp .org/articles/abu-odeh.shtml.

Ali, Abdullah Yusuf. 1989. The Meaning of the Holy Qur'an. Bestville, MD: Amana.

Ali, Kecia. 2003. "Progressive Muslims and Islamic Jurisprudence: The Necessity for Critical Engagement with Marriage and Divorce Law." In Progressive Muslims on Justice, Gender, and Pluralism, edited by Omid Safi, 164-89. Oxford: One World.

Al-Sharmani, Mulki. 2011. "Islamic Feminism and Reforming Muslim Family Laws," European University Institute Working Paper RSCAS 2011/29, Robert Schuman Centre for Advanced Studies, Mediterranean Programme, 1-24.

Al-Sharmani, Mulki. 2012. "Egyptian khul': Legal Reform, Courtroom Practices, and Realities of Women." In Interpreting Divorce Laws in Islam edited by Rubya Mehdi, Werner Menski, and Jørgen S. Nielsen, 85-105. Copenhagen, Denmark: DJǿF Publishing.

Al-Sharmani, Mulki. 2013a. "Reforming Egyptian Family Laws: The Debate about a New Substantive Code." In Feminist Activism: Women's Rights and Legal Reform. Edited by Mulki Al-Sharmani, 73-100. New York and UK: Zed books.

Al-Sharmani, Mulki. 2013b. "Qiwāma in Egyptian Family Laws: Wifely Obedience between Legal Texts, Court Room Practices, and Realities of Marriages." In Gender and Equality in Muslim Family Law: Justice and Ethics in the Islamic Legal Tradition, 
edited by Ziba Mir-Hosseini, Kari Vogt, Lena Larsen and Christian Moe, 37-56. London: I. B. Tauris.

Al-Sharmani, Mulki. 2013c. "Reflections on Islamic Feminist Readings of Jurisprudence and its Relevance for the Egyptian Context." In Islamic and Feminist Perspectives: New Horizons of Knowledge and Reform, edited by Omaima Abou-Bakr, 136-49. Cairo: Egypt: Women and Memory Forum, in cooperation with the Danish-Egyptian Dialogue Institute (DEDI) and the Danish Center for Research on Women and Gender (KVINFO).

Al-Sharmani, Mulki. 2014a. "Narratives of Egyptian Marriages." In Changing Narratives of Sexuality, edited by Charmaine Pereira, 193-217. London: Zed Books.

Al-Sharmani, Mulki. 2014b. "Legal Reform, Women's Empowerment, and Social Change: The Case of Egypt." In Feminisms, Empowerment and Development: Changing Women's Lives edited by Andria Cornwall and Jenny Edwards, 32-48. London: Zed Books.

Al-Sharmani, Mulki. 2014c. "Islamic Feminism:Transnational and National Reflections." Approaching Religion 4, 2: 83-94.

Al-Sharmani, Mulki. 2015. "Striving against the Nafs: Revisiting Somali Muslim Spousal Roles and Rights in Finland." Journal of Religion in Europe 8: 101-120.

Al-Sharmani, Mulki. 2016. "Contemporary Egyptian Islamic Feminism: Possibilities and Challenges" Afriche Orienti anno XVIII, 1/2016: 58-77.

Al-Sharmani, Mulki. 2017a. Gender Justice and Legal Reform in Egypt: Negotiating Muslim Family Law. Cairo, Egypt: the American University in Cairo Press.

Al-Sharmani, Mulki. 2017b. "Divorce among Transnational Finnish Somalis: Gender, Religion, and Agency." Religion and Gender 7, 1: 70-87.

Al-Sharmani, Mulki. Forthcoming. "Muslim Family Wellbeing and Integration in Finland: The Role of Mosques." In Wellbeing of Transnational Muslim Families: Marriage, Law and Gender edited by Marja Tillikainen, Mulki Al-Sharmani, and Sanna Mustasaari. London and New York: Routledge.

Al-Sharmani, Mulki and Rumminger,Jana. 2015. "Understanding Qiwamah and Wilayah through Life Stories". In Men in Charge? Rethinking Authority in Muslim Legal Tradition, edited by Ziba Mir-Hosseini, Mulki Al-Sharmani, and Jana Rumminger, 219-55. Oxford, UK: OneWorld.

Al-Sharmani, Mulki, Mustasaari, Sanna and Ismail, Abdirashid A. 2017. "Faith-based Family Dispute Resolution in Finnish Mosques: Unfolding Roles and Evolving Practices." In Gender and Justice in Family Law Disputes: Women, Mediation and Religious Arbitration, edited by Samia Bano, 270-91. Waltham, MA: Brandeis University Press.

Bukhārī, Muhammad ibn Isma'il al-. 1974. Sahīh al-Bukhāri. Translated by Muhammad Muhsin Khan, 9 vols. Medina: Islamic University. 
Kääriäinen, Kimmo. 2011. "Religion and State in Finland." Nordic Journal of Religion and Society 24(2): 155-171.

Mir-Hosseini, Ziba. 2003. "The Construction of Gender in Islamic Legal Thought and Strategies for Reform." Hawwa 1,1: 1-28.

Mir-Hosseini, Ziba. 2013. "Justice, Equality and Muslim Family Laws: New Ideas, New Prospects." In Gender and Equality in Muslim Family Law, edited by Ziba MirHosseini, Kari Vogt, Lena Larsen and Christin Moe, 7-36. London and New York: I. B. Tauris.

Mir-Hosseini, Ziba, Al-Sharmani, Mulki and Rumminger, Jana (eds.). 2015. Men in Charge? Rethinking Authority in Muslim Legal Tradition. Oxford: OneWorld.

Mir-Hosseini, Ziba and Anwar, Zainah. 2012. "Decoding the "DNA of Patriarchy" in Muslim Family Laws." In Open Democracy May 2012.

Mustasaari, Sanna and Al-Sharmani, Mulki. "Betweeen 'Official' and 'Unofficial:' Discourses and Practices of Muslim Marriage Conclusion in Finland." In Oxford Journal of Law and Religion, 2018. https://academic.oup.com/ojlr/advance-article -abstract/doi/10.1093/ojlr/rwyo29/5067187? redirectedFrom=fulltext.

OSF. 2013. Somalis in Helsinki. New York and London: Open Society Foundations.

Pauha, Teemu, and Tuomas Martikainen. 2014. "Finland." In Yearbook of Muslims in Europe, Vol. 6, edited by Jørgen S. Nielsen, Samim Akgönül, Ahmet Alibašić Jørgen Nielsen, Samim Akgönül, Ahmet Alibašić and Egdūnas Račius, 218-228. Leiden: Brill.

Peltola, Marja. 2016. "Respectable Families: Discourses on Family Life, Ethnic Hierarchies and Social Positioning." Ethnicities, 16(1): 22-39.

Shaikh, Sacdiyya. 2015. "Islamic Law, Sufism, and Gender: Rethinking the Terms of Debate." In Men in Charge? Rethinking Authority in Muslim Legal Tradition, edited by Ziba Mir-Hosseini, Mulki Al-Sharmani, and Jana Rumminger. 106-131. Oxford: OneWorld.

Statistics of Finland. 2018. "Population Structure." Accessed 10 April 2018. https://www .stat.fi/til/vrm_en.html.

Statistics Finland, 2016. "Population structure. Language according to age and sex by region in 1990 to 2016." Accessed 2 January 2018. http://pxnet2.stat .fi/PXWeb/pxweb/en/StatFin/StatFin__vrm__vaerak/statfin_vaerak_pxt_o1o .px/?rxid=40252902-b370-44ea-8183-d2fc305596e6.

Tucker, Judith. 2008. Women, Family, and Gender in Islamic Law. Cambridge: Cambridge University Press.

Wadud, Amina. 2015. "The Ethics of Tawhid over the Ethics of Qiwamah" In Men in Charge? Rethinking Authority in Muslim Legal Tradition, edited by Ziba Mir-Hosseini, Mulki Al-Sharmani, and Jana Rumminger, 256-74. Oxford: OneWorld.

Wadud, Amina. 2004."Qur'ān, Gender, and the Interpretive Possibilities." Hawwa 2,3: $316-36$. 